\title{
Growth rate of body weight and measurements in pheasants reared up to the 24th week of life (Short Communication)
}

\author{
JOANNA KUŹNIACKA and MAREK ADAMSKI
}

Department of Poultry Breeding, University of Technology and Life Science in Bydgoszcz, Poland

\begin{abstract}
The aim of the present research was to evaluate the growth rate of the weight and body measurements of pheasants reared up to the 24th week of life, fed with all-mash mixtures. In the 3rd, 8th, 12th , 16th, 20th and 24th week of life the birds were weighed individually and their body measurements were measured based on which the growth rate indices of the traits researched were calculated. It was found that the body weight of pheasants of both sexes was increasing with the bird age, however there were noted no significant differences of that trait between the 16th and the 20th and the 20th and the 24th week of rearing. As for all the evaluation dates, except or the 3rd week of rearing, sexual dimorphism of the body weight was clearly seen, which was significant $(P \leq 0.05)$. Similarly as the weight, also the pheasant body measurements were increasing on successive rearing dates. Between the 20th and the 24th week of rearing no significant differences were recorded in most of the traits evaluated. Sexual dimorphism concerning the body measurements was found in birds starting from the 12th or the 16th week of life. The highest growth rate of the body weight and measurements was observed in pheasants up to the 8th week of rearing. The growth rate of all the body measurements was decreasing after the 16th week of rearing, which shows that the pheasant growth was completed.
\end{abstract}

Keywords: pheasant, body weight, body measurements, growth rate

\section{Zusammenfassung}

\section{Wachstumsrate des Lebendgewichts und der Körpermaße bei Fasanen bis zur 24. Lebenswoche (Kurzmitteilung)}

Untersucht wurden die Wachstumsraten von Körpergewicht und Körpermaßen von 64 Fasanen bis zu einem Alter von 24 Lebenswochen. Gefüttert wurden die Tiere altersabhängig mit unterschiedlichem Alleinfutter. Gewichte und Körpermaße wurden nach der 3., 8., 12., 16. und 24. Woche zur Berechnung der Wachstumsrate erfasst. Zwischen den Geschlechtern bestanden sowohl bei den Körpergewichten als auch den Körpermaßen, abgesehen von den Werten der 20. und 24. Woche, signifikante Unterschiede. Deutlich nachweisbar war der Geschlechtsdimorphismus nach der 12. bzw. 16. Woche. Die größten Wachstumsraten erreichten die Tiere bis zur 8. Lebenswoche. Die Wachstumsrate aller 
Körpermaße verringerte sich vor allem nach der 16. Lebenswoche wodurch sich das Ende des Wachstums der untersuchten Fasane andeutet.

Schlüsselwörter: Fasan, Lebendgewicht, Körpermaße, Wachstumsrate

\section{Introduction}

The research on pheasant growth carried out so far (JAMROZ et al. 1987, MAZURKIEWICZ et al. 1991, KOTRBÁČEK et al. 1996, KJAER 1997, MARZONI et al. 2005, VEČEREK et al. 2005, STRAKOVÁ et al. 2006) concerned mostly the effect of different environmental factors (feeding, light, keeping system) or genetic factors (bird origin) on the weight and some body measurements in pheasants at the initial growth period. Such researches which involved older pheasants were reported by KRYSTIANIAK and TORGOWSKI 1998, NOWACZEWSKI et al. 1999, SAGE et al. 2002). Literature, however, offers less information on the body measurements and indices of the growth rate of the body weight and measurements in pheasants at different age.

In Poland pheasants obtained from aviary breeding supply mostly hunting-grounds, and are less used as slaughter birds. However over the recent years there has been observed a growing interest in pheasants as a source of ssafer meat, as well as different than that from broiler chickens, reared traditionally. All that called for taking up research on the growth rate in this bird species and making an attempt at defining the optimal age at which rearing should be completed. The aim of the present research was to evaluate the indices of growth rate of the body weight and measurements in pheasants reared up to the 24th week of life, fed with all-mash mixtures starter, grower and finisher.

\section{Material and methods}

The present research was made on the game bird farm in the Kujawsko-Pomorskie Province, Poland. The experimental material was made up of 64 pheasants reared up to the 24th week of life. Up to the 8th week the birds were kept in the rearing house under controlled environmental conditions, and starting from the 9th week to the end of rearing in partially roofed aviaries. Up to the 8th week of rearing only the pheasants were fed with all-mash pelleted mixture starter, where $1 \mathrm{~kg}$ of feed contained $27.32 \%$ of protein and $2800 \mathrm{kcal}$ ME. From the 9th to the 16th week the birds were given the grower mixture, containing $24.21 \%$ of protein and $2765 \mathrm{kcal} \mathrm{ME}$, while starting from the 17th week to the end of rearing the finisher mixture (18.06\% of protein and $2750 \mathrm{kcal} \mathrm{ME})$. Additionally from the 9th week of rearing pheasants were given ad libitum leaves and Jerusalem artichoke tubers as well as fodder beets. Pheasant feeding complied with the nutrition guidelines for this bird species (SMULIKOWSKA and RUTKOWSKI 2005).

In the $3 \mathrm{rd}, 8 \mathrm{th}, 12 \mathrm{th}, 16 \mathrm{th}, 20$ th and 24th week of rearing the pheasant body weight was individually controlled with the accuracy up to $5 \mathrm{~g}$. At the same dates there were also made bird body measurements following the method given by ADAMSKI and KUŹNIACKA (2006). The measuring tape up to $0.1 \mathrm{~cm}$ accurate was used to measure the length of the trunk, breast bone, forearm and shank as well as the chest circumference. The slide calliper up to $0.1 \mathrm{~mm}$ accurate was used to measure the chest depth and the shank 
thickness. The measurements taken facilitated the calculation of the indices of the growth rate (\%) of the pheasant traits in both sexes according to the following formula:

$$
t_{w}=\frac{m_{k}-m_{p}}{0.5\left(m_{k}+m_{p}\right)} \cdot 100
$$

where $t_{w}$ is the growth rate, $m_{k}$ is the value of a given trait at the end of the period researched, $m_{p}$ is the value of a given trait at the beginning of the period researched.

The numerical data were verified statistically using Statistica PL software (2002). There were calculated mean values $(\mathrm{x})$ and variation coefficients $(\mathrm{v})$ of the traits researched. Significance of the differences in the traits researched between the weeks of rearing and the sex were verified using the Sheffē test.

\section{Results}

The body weight of pheasants of both sexes in total (Table 1) was increasing in successive weeks of life and ranged from $137 \mathrm{~g}$ (3rd week) to $1275 \mathrm{~g}$ (24th week), however there were recorded no significant differences in that trait between the 16th and the 20th and between the 20th and the 24th week of rearing. At all the evaluation dates, except for the 3 rd week, sexual dimorphism was clearly seen concerning the body weight, which was significant $(P \leq 0.05)$.

Similarly as the body weight, also the pheasant body measurements (Table 1 and 2) were increasing at successive rearing dates. Between the 20th and the 24th week of rearing there were noted no significant differences in the traits evaluated. The forearm length was the only one which demonstrated no significant differences also between the 16th and 24th week of bird life. Sexual dimorphism, as for most body measurements, was observed in pheasants starting from the 12th or the 16th week of life, except for the length of shank for which no significant differences were found.

The variation coefficients of the body weight were average and in males ranged from 7.0 to $13.6 \%$ and in females - from 7.8 to $16.1 \%$. As for the length of the trunk and breast bone there were recorded higher variation coefficient values at the beginning of rearing and with age the flock was getting uniform as far as these traits were concerned. The variation coefficient values of the other body measurements were low.

The highest growth rate of the body weight and measurements (Figure) were recorded in pheasants up to the 8th week of rearing, however the body weight growth expressed as a percentage was highest up to the 3rd week of life and accounted for $147 \%$, from the $3 \mathrm{rd}$ to the 8 th week of life $-119 \%$, and at successive evaluation dates it was clearly decreasing. Besides the chest depth the growth of which between the 8th and the 12th week decreased only by $12 \%$ as compared with the period between the $3 \mathrm{rd}$ and the 8th week (Figure), there was observed a clear decrease in the growth rate of all the characters starting from the 8th week of bird life. The rate of growth of all the body measurements was decreasing till the end of rearing, which demonstrates that the pheasant growth has been completed. For most traits there were found no significant differences between the last two or three rearing dates evaluated. 
Body weight

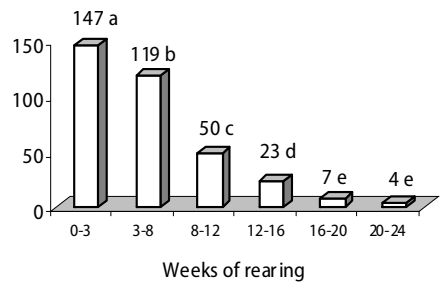

Breast bone length

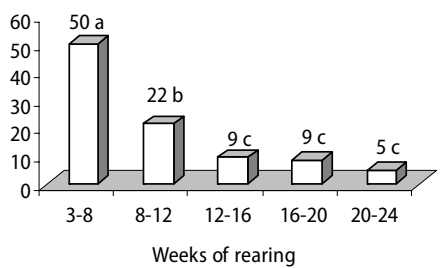

Chest circumference

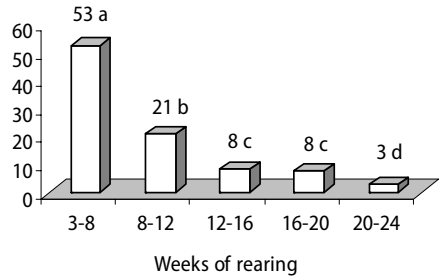

Shanklength

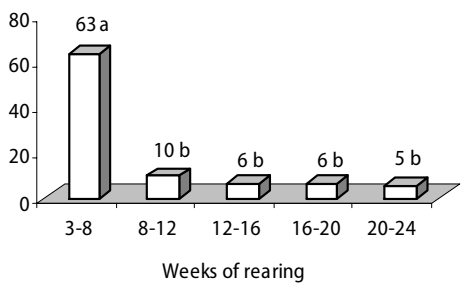

Trunk length

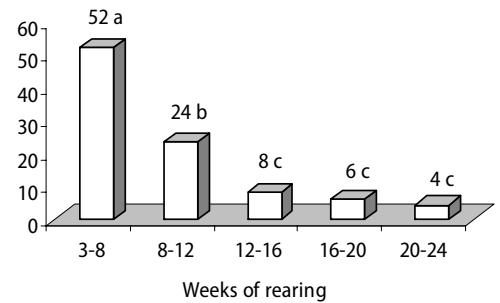

Forearm length

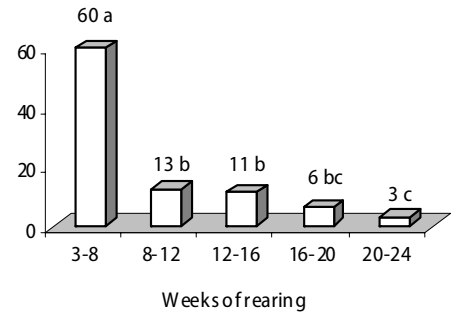

Chest depth

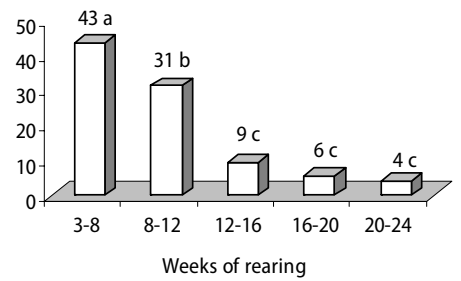

Shank thickness

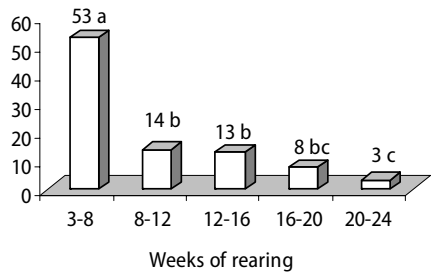

$a, b, c, d, e$ Mean values of the traits in total for pheasants of both sexes marked with different letters differ significantly between week $(P \leq 0.05)$. * $\quad$ Significant differences in traits between males and females were not observed $(P \leq 0.05)$.

Figure

Indices of growth rate* $(\%)$, body weight and measurements in pheasants

Indikatoren der Wachstumsrate* (\%), des Lebendgewichts und der Körpermaße bei Fasanen 
Table 1

Mean values $(x)$ and variation coefficients $(v)$ of the body weight, length of trunk, breast bone and forearm in pheasants

Mittelwerte (x) und Variationskoeffizienten (v) für das Lebendgewicht, die Rumpflänge, die Länge des Brustbeinkamms und des Unterarms bei Fasanen

\begin{tabular}{|c|c|c|c|c|c|c|c|}
\hline \multirow[t]{2}{*}{ Trait } & \multirow{2}{*}{$\begin{array}{l}\text { Week of } \\
\text { rearing }\end{array}$} & \multicolumn{6}{|c|}{ Sex - statistical measures } \\
\hline & & $x$ & $\mathrm{v}$ & $\mathrm{x}$ & v & $\mathrm{x}$ & $\mathrm{v}$ \\
\hline \multirow{6}{*}{ Body weight, g } & 3 & 143 & 13.6 & 129 & 16.1 & $137^{\mathrm{e}}$ & 15.3 \\
\hline & 8 & 580 & 11.2 & 488 & 10.8 & $541^{d *}$ & 13.9 \\
\hline & 12 & 984 & 8.8 & 769 & 8.3 & $900^{c *}$ & 14.6 \\
\hline & 16 & 1272 & 7.0 & 918 & 7.9 & $1142^{\mathrm{b*}}$ & 16.7 \\
\hline & 20 & 1362 & 6.0 & 962 & 7.8 & $1229^{\mathrm{ab} *}$ & 16.8 \\
\hline & 24 & 1400 & 8.3 & 978 & 10.5 & $1275^{a *}$ & 17.7 \\
\hline \multirow{6}{*}{ Trunk length, $\mathrm{cm}$} & 3 & 8.4 & 9.5 & 7.9 & 11.4 & $8.2^{\mathrm{b}}$ & 11.0 \\
\hline & 8 & 14.3 & 7.7 & 13.5 & 8.1 & $14.0^{\mathrm{b}}$ & 8.6 \\
\hline & 12 & 18.1 & 6.6 & 16.5 & 6.1 & $17.5^{\mathrm{b} *}$ & 8.0 \\
\hline & 16 & 19.0 & 5.3 & 17.1 & 5.8 & $18.3^{\mathrm{b} *}$ & 7.1 \\
\hline & 20 & 20.0 & 4.5 & 17.7 & 5.6 & $19.2^{\mathrm{a} *}$ & 7.8 \\
\hline & 24 & 20.4 & 4.9 & 18.2 & 6.0 & $19.7^{\mathrm{a} *}$ & 7.1 \\
\hline \multirow{6}{*}{ Breast bone length, $\mathrm{cm}$} & 3 & 4.6 & 15.2 & 4.4 & 18.2 & $4.5^{\mathrm{b}}$ & 15.5 \\
\hline & 8 & 7.7 & 9.1 & 7.1 & 8.4 & $7.4^{\mathrm{b}}$ & 9.4 \\
\hline & 12 & 9.4 & 6.4 & 8.4 & 5.9 & $9.0^{\mathrm{b} *}$ & 7.8 \\
\hline & 16 & 10.3 & 6.8 & 8.9 & 6.7 & $9.8^{\mathrm{b} *}$ & 9.2 \\
\hline & 20 & 11.2 & 4.5 & 9.5 & 7.4 & $10.6^{\mathrm{a} *}$ & 9.4 \\
\hline & 24 & 11.6 & 4.3 & 10.4 & 7.7 & $11.3^{\mathrm{a} *}$ & 7.1 \\
\hline \multirow{6}{*}{ Forearm length, $\mathrm{cm}$} & 3 & 3.8 & 10.5 & 3.6 & 8.3 & $3.7^{c}$ & 10.8 \\
\hline & 8 & 7.0 & 8.6 & 6.7 & 8.9 & $6.9^{\mathrm{b}}$ & 8.7 \\
\hline & 12 & 7.3 & 6.8 & 6.7 & 6.0 & $7.1^{\mathrm{b}}$ & 7.0 \\
\hline & 16 & 8.2 & 8.5 & 7.1 & 7.0 & $7.8^{\mathrm{a} *}$ & 10.2 \\
\hline & 20 & 8.2 & 6.1 & 7.5 & 9.3 & $7.9^{\mathrm{a} *}$ & 7.6 \\
\hline & 24 & 8.5 & 5.9 & 7.8 & 5.1 & $8.2^{\mathrm{a}}$ & 7.3 \\
\hline
\end{tabular}

$\mathrm{a}, b, c, d, e$ mean values of the traits in columns in total for pheasants of both sexes marked with different letters differ significantly between week $(P \leq 0.05), \quad *$ significant differences in traits between males and females $(P \leq 0.05)$

\section{Discussion}

KJAER (1997), investigating the effect of the intensity of light on the pheasant growth up to the 6th week of life, recorded about 11 to $17 \mathrm{~g}$ lower bird body weight in the 3rd week of rearing as compared with the results reported in the present research. The results of the present research (Table 1) show that 8-and 12-week old birds were heavier than those reported by other authors (MAZURKIEWICZ et al. 1991, TORGOWSKI and POTKAŃSKI 1994, SEVERIN et al. 2007). SAGE et al. (2002) applying high-protein diet in pheasants from the 6th to the 16th or from the 6th to the 10th week of rearing, found in the latter a slightly lower body weight in 16-week-old males and similar in females, as compared with the present research. Similar values of the body weight at the same age in three genetically different populations of pheasants were shown by KRYSTIANIAK and TORGOWSKI (1998). 
Table 2

Mean values ( $\mathrm{x}$ ) and variation coefficients (v) in the measurements of chest and shank in pheasants Mittelwerte $(x)$ und Variationskoeffizienten ( $v$ ) für die Thorax- und Laufmaße bei Fasanen

\begin{tabular}{|c|c|c|c|c|c|c|c|}
\hline \multirow{3}{*}{ Trait } & \multirow{3}{*}{$\begin{array}{l}\text { Week of } \\
\text { rearing }\end{array}$} & \multicolumn{6}{|c|}{ Sex - statistical measures } \\
\hline & & \multicolumn{2}{|c|}{ 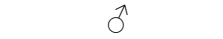 } & \multicolumn{2}{|c|}{ 우 } & \multicolumn{2}{|c|}{$\widehat{\delta}$ 우 } \\
\hline & & $x$ & v & $x$ & v & $x$ & v \\
\hline \multirow{6}{*}{ Chest circumference, $\mathrm{cm}$} & 3 & 11.8 & 5.9 & 11.5 & 6.9 & $11.7^{\mathrm{e}}$ & 6.0 \\
\hline & 8 & 20.3 & 5.4 & 19.6 & 6.6 & $20.0^{\mathrm{d}}$ & 6.5 \\
\hline & 12 & 24.8 & 14.1 & 23.4 & 4.3 & $24.2^{c}$ & 12.0 \\
\hline & 16 & 27.4 & 4.7 & 24.4 & 4.5 & $26.3^{\mathrm{b} *}$ & 7.2 \\
\hline & 20 & 29.5 & 3.0 & 26.6 & 4.5 & $28.6^{\mathrm{a} *}$ & 5.9 \\
\hline & 24 & 30.3 & 3.3 & 27.1 & 4.4 & $29.3^{\mathrm{a*}}$ & 6.1 \\
\hline \multirow{6}{*}{ Chest depth, mm } & 3 & 45.2 & 7.1 & 43.6 & 9.6 & $44.5^{e}$ & 8.3 \\
\hline & 8 & 71.5 & 10.5 & 66.7 & 8.1 & $69.4^{\mathrm{d}}$ & 10.1 \\
\hline & 12 & 100.4 & 5.9 & 87.2 & 6.6 & $95.2^{c *}$ & 9.1 \\
\hline & 16 & 106.4 & 18.1 & 93.0 & 4.3 & $101.5^{\mathrm{b} *}$ & 16.5 \\
\hline & 20 & 110.4 & 4.7 & 95.3 & 4.7 & $105.4^{\mathrm{ab} *}$ & 8.2 \\
\hline & 24 & 115.0 & 5.6 & 98.7 & 4.5 & $110.2^{\mathrm{a} *}$ & 8.6 \\
\hline \multirow{6}{*}{ Shank length, cm } & 3 & 2.8 & 7.1 & 2.6 & 7.7 & $2.7^{\mathrm{d}}$ & 7.4 \\
\hline & 8 & 5.3 & 7.5 & 5.0 & 8.0 & $5.2^{c}$ & 7.7 \\
\hline & 12 & 5.6 & 7.1 & 5.1 & 3.9 & $5.4^{\mathrm{b}}$ & 7.4 \\
\hline & 16 & 5.6 & 5.3 & 4.9 & 6.1 & $5.3^{b c}$ & 9.4 \\
\hline & 20 & 5.7 & 3.5 & 4.9 & 4.1 & $5.5^{\mathrm{ab}}$ & 7.3 \\
\hline & 24 & 6.0 & 3.3 & 5.2 & 7.7 & $5.7^{\mathrm{a}}$ & 7.0 \\
\hline \multirow{6}{*}{ Shank thickness, mm } & 3 & 3.6 & 8.3 & 3.3 & 9.1 & $3.5^{\mathrm{d}}$ & 8.6 \\
\hline & 8 & 6.2 & 8.1 & 5.7 & 10.5 & $6.0^{c}$ & 10.0 \\
\hline & 12 & 7.0 & 8.6 & 6.1 & 6.5 & $6.7^{\mathrm{b*}}$ & 10.4 \\
\hline & 16 & 7.9 & 35.4 & 6.5 & 10.8 & $7.4^{\mathrm{ab} *}$ & 31.1 \\
\hline & 20 & 7.7 & 6.5 & 6.4 & 4.7 & $7.3^{\mathrm{ab} *}$ & 10.9 \\
\hline & 24 & 7.9 & 6.4 & 6.6 & 10.0 & $7.5^{\mathrm{a} *}$ & 10.7 \\
\hline
\end{tabular}

$a, b, c, d, e$ mean values of the traits in columns in total for pheasants of both sexes marked with different letters differ significantly between week $(P \leq 0.05),{ }^{*}$ significant differences in traits between males and females $(P \leq 0.05)$

Similarly as in the present research, significant sexual dimorphism in the body weight in the 8th, 12th and 16th week of life in pheasants was reported by NOWACZEWSKI et al. (1999), as well as SAGE et al. (2002) in 16-week-old birds. In the experiments by SEVERIN et al. $(2006,2007)$ cocks at the same age were heavier; $1512 \mathrm{~g}$ (20th week) and 1485 $1540 \mathrm{~g}$ (24th week), as compared with the present results.

Pheasant body measurements (the length of trunk, breast bone and shank) reported by WINNICKA (cited after MRÓZ 2003) evaluated at similar dates of rearing in most cases were bigger than those in the present research, both in cocks and in hens, except for the length of the trunk measured in the 16th and the 20th week of life, the length of breast bone in the 8th week of life in pheasants of both sexes and in 24-week-old hens, which coincided with the present research. Higher values of some body measurements were also reported by NOWACZEWSKI et al. (1999) and SAGE et al. (2002).

The reports by WINNICKA (cited after MRÓZ 2003) confirm the greatest growth rate of the body weight and measurements in pheasants up to the 8th week of life; the author also demonstrated that similar values of the growth rate indices between the 8th and the 12 th and between the 12 th and the 16 th week of pheasant rearing, but slightly higher 
between later evaluation dates as compared with the present results (Figure). As seen from Figure, slowed-down growth rate of the body weight in pheasants after the 16th week of life is also confirmed by SEVERIN et al. (2007).

To sum up, one can observe that the body weight and measurements in pheasants of both sexes increased significantly up to the 16th or the 20th week of rearing. Starting from the 8th week the body weight and from the 12th or 16th week most body measurements demonstrated a clear sexual dimorphism. A decreased growth rate of the body weight and measurements after the 16th week of life, no significant differences in the values of the traits analyzed between the 20th and the 24th week of life shows a completed bird growth as well as points to a possibility of completing pheasant rearing earlier, namely between the 16 th and the 20th week.

\section{References}

Adamski M, Kuźniacka J (2006) The effect of age and sex on slaughter traits of pheasants (Phasianus colchicus L.). Anim Sci Papers \& Reports 24 Suppl 2, 11-8

Jamroz D, Mazurkiewicz M, Bartczak R (1987) Application of dry mash mixtures of a lowered protein level, made from domestic components in pheasant rearing. Med Wet 43, 295-7 [in Polish]

Kjaer J B (1997) Effect of light intensity on growth, feed intake and feather pecking behaviour in beak trimmed and bitted pheasant chickens (Phasianus colchicus). Arch Geflügelk 61, 167-71

Kotrbáček V, Filka J, Halouzka R, Hanák L (1996) The use of biomass of chlorococcal algae (Chlorella vulgaris) for the nursing of pheasants. Vet Med - Czech 41, 87-91

Krystianiak S, Torgowski J (1998) Effect of two feeding systems on the results of rearing in pheasants (Phasianus cochicus L.) of Polish and French variety. Zesz Nauk PTZ Prz Hod 36, $201-9$ [in Polish]

Marzoni M, Castillo A, Romboli I (2005) Dietary inclusion of Quebracho (Schinopsis lorentzi) tannins on productive performances of growing pheasant females. Ital J Anim Sci 4 Suppl 2, 213-9

Mazurkiewicz M, Jamroz D, Bartczak R, Gaweł A (1991). Effect of livex on the development and health status of growing pheasants. Med Wet 46, 35-7 [in Polish]

Mróz E (2003). Pheasants. Oficyna wyd Hoża (ed). Warszawa, Poland [in Polish]

Nowaczewski S, Krystianiak S, Kontecka H, Torgowski J (1999) Characteristics of selected phenotypic characters in pheasants kept on the farm in Gorzyń. Zesz Nauk PTZ Prz Hod 45, 183-4 [in Polish]

Sage R B, Putaala A, Woodburn M I A (2002) Comparing growth and condition in post release juvenile common pheasants on different diets. Poult Sci 81, 1199-202

Severin K, Mašek T, Janicki Z, Konjević D, Slavica A, Hrupački T (2006) Copunisation of pheasants at different age. Vet Arhiv Suppl 76, 211-9

Severin K, Mašek T, Horvatek D, Konjević D, Janicki Z, Cvrtila Ž, Kozačinski L, Hadžiosmanovič M, BarićRafaj R (2007) The effects of castration on the growth parameters, carcass yield and meat chemical composition of intensively reared common pheasant (Phasianus colchicus colchicus L.). Ital J Anim Sci 6, 213-9

Smulikowska S, Rutkowski A (Complete Edition) (2005) Nutrition guidelines and the nutritive value of feeds. Poultry nutrition standards. Institute of Animal Physiology and Nutrition of the Polish Academy of Sciences, 4th edition, 93-5 [in Polish]

Statistica PI (2002) Version 6 series 1101, Krakow, Poland

Straková E, Suchý P, Vitula F, Večerek V (2006) Differences in the amino acid composition of muscles from pheasant and broiler chickens. Arch Tierz 49, 508-14

Torgowski J, Potkański A (1994) Effect of various levels of protein in the diets for pheasants on their growth. VIII International Young Poultry Symposium Bydgoszcz-Pieczyska 9-11 VI, 127 [in Polish]

Večerek V, Suchý P, Straková E, Vitula F, Mikundová M (2005) Variation in the chemical composition of muscles in young pheasants during their growth. Arch Tierz 48, 290-8 
Corresponding author:

JOANNA KUŹNIACKA

email: kuzniacka@utp.edu.pl

Department of Poultry Breeding, University of Technology and Life Science in Bydgoszcz, Mazowiecka 28, 85-084 Bydgoszcz, Poland 